\title{
ANY PRESS IS GOOD PRESS? THE UNANTICIPATED EFFECTS OF TITLE IX INVESTIGATIONS ON UNIVERSITY OUTCOMES
}

\author{
Jason M. Lindo \\ Dave E. Marcotte \\ Jane E. Palmer \\ Isaac D. Swensen \\ Working Paper 24852 \\ http://www.nber.org/papers/w24852
NATIONAL BUREAU OF ECONOMIC RESEARCH
1050 Massachusetts Avenue
Cambridge, MA 02138
July 2018

The views expressed herein are those of the authors and do not necessarily reflect the views of the National Bureau of Economic Research.

At least one co-author has disclosed a financial relationship of potential relevance for this research. Further information is available online at http://www.nber.org/papers/w24852.ack

NBER working papers are circulated for discussion and comment purposes. They have not been peer-reviewed or been subject to the review by the NBER Board of Directors that accompanies official NBER publications.

(C) 2018 by Jason M. Lindo, Dave E. Marcotte, Jane E. Palmer, and Isaac D. Swensen. All rights reserved. Short sections of text, not to exceed two paragraphs, may be quoted without explicit permission provided that full credit, including $\left({ }^{\circ}\right.$ notice, is given to the source. 
Any Press is Good Press? The Unanticipated Effects of Title IX Investigations on University Outcomes

Jason M. Lindo, Dave E. Marcotte, Jane E. Palmer, and Isaac D. Swensen

NBER Working Paper No. 24852

July 2018

JEL No. I1,I23,J16,J71,K38,K42

\section{ABSTRACT}

Since 2011, when the landmark "Dear Colleague" letter declared that the Department of Education (DoE) would use equal-access requirements of federal law to remediate sexual assault on college campuses, 458 investigations have been opened. This letter was withdrawn in 2017 and it remains uncertain how the DoE will handle the issue in the future. We examine the effects of the investigations arising from the 2011 policy change on university outcomes. We find that applications and enrollment increase in response to Title IX investigations, for both males and females. We find little evidence of effects on degree completion or donations.

Jason M. Lindo

Department of Economics

Texas A\&M University

4228 TAMU

College Station, TX 77843

and NBER

jlindo@econmail.tamu.edu

Dave E. Marcotte

School of Public Affairs

American University

4400 Massachusetts Avenue NW

Washington, DC 20016

marcotte@umbc.edu
Jane E. Palmer

School of Public Affairs

American University

jane.palmer@american.edu

Isaac D. Swensen

Department of Agricultural Economics, and Economics

Montana State University

P.O. Box 17290

Bozeman, MT 59717

isaac.swensen@montana.edu 


\title{
Any Press is Good Press? The Unanticipated Effects of Title IX Investigations on University Outcomes
}

\author{
By Jason M. Lindo, Dave E. Marcotte, Jane E. Palmer, and Isaac D. Swensen*
}

Since 2011, when the landmark "Dear Colleague" letter declared that the Department of Education (DoE) would use equal-access requirements of federal law to remediate sexual assault on college campuses, 458 investigations have been opened. This letter was withdrawn in 2017 and it remains uncertain how the DoE will handle the issue in the future. We examine the effects of the investigations arising from the 2011 policy change on university outcomes. We find that applications and enrollment increase in response to Title IX investigations, for both males and females. We find little evidence of effects on degree completion or donations.

In September 2017, Secretary Betsy DeVos formally withdrew an influential but controversial policy providing guidance on the responsibilities of the U.S. Department of Education (DoE) to monitor how American colleges and universities investigate and resolve sexual assault cases involving students. ${ }^{1}$ This rescission of a policy, which was put in place during the administration of President Obama by a "Dear Colleague" letter (DCL) from the Office of Civil Rights (OCR), was momentous because it ended what had been steady, if halting, advances in federal action to prevent and respond to sexual assault and protect victims. In particular, "Dear Colleague" policy guidance marked the advent of the use of equal access requirements of federal law to bring attention and remediation to sexual assault on college campuses. When the DCL was released in 2011, there were only a handful of schools under investigation by OCR. By June 2017, that number had grown to more than 400 (Brown, 2017). Since the September 2017 withdrawal of the OCR guidance, the rate of federal investigations of how universities respond to Title IX cases has slowed considerably—13 new investigations were initiated in the 6 months following that action, compared to 44 investigations over the same period the previous year (Chronicle of Higher Education, 2018).

\footnotetext{
*Lindo: Department of Economics, Texas A\&M University, NBER, and IZA. Marcotte: School of Public Affairs, American University and IZA. Palmer: School of Public Affairs, American University. Swensen: Department of Agricultural Economics and Economics, Montana State University

${ }^{1}$ https://www2.ed.gov/about/offices/list/ocr/letters/colleague-title-ix-201709.pdf
} 
Moreover, there is considerable uncertainty about what the policy will look like in the future. In October 2017, the OCR released a "Q\&A” on the matter of Title IX investigations pertaining to sexual harassment. This Q\&A document provides interim guidance for universities while the DoE conducts “rulemaking on the topic of schools’ Title IX responsibilities concerning complaints of sexual misconduct, including peer-on-peer sexual harassment and sexual violence." This rulemaking process is scheduled to conclude with the announcement of new guidance on Title IX claims sometime in 2018.

While current policy is in limbo, in this paper we evaluate the impacts of Title IX investigations for sexual assault as implemented following the 2011 DCL. That period ushered in an era of unprecedented attention to matters of sexual assault on college campuses in the United States. We examine the effects of this attention on college applications, enrollment, degree completion and alumni giving. This is important both to evaluate the impacts of a major policy decision in higher education and also to potentially to inform the evolving oversight responsibilities of the U.S. Department of Education. ${ }^{2}$

There are three types of mechanisms through which Title IX investigations can affect prospective and current students, and alumni: information, salience, and change. First, these investigations may reveal characteristics about colleges and universities that are typically hard to measure. Because these investigations are based on complaints that instances of sexual violence were not properly investigated or adjudicated, they may signal that a college or university is not safe or does not take sexual assault seriously. Perversely, investigations may provide information about the college atmosphere that is desirable to some individuals, e.g., party culture. ${ }^{3} \mathrm{~A}$ salience mechanism could be relevant if a Title IX investigation increases the likelihood that time- and attention-limited individuals consider the institution when making decisions about where to apply, or where to make donations. Finally, Title IX investigations may change universities in ways that matter to students and other interested parties. Perhaps most immediately, one might expect federal investigations to improve the way sexual violence cases are investigated and adjudicated. Secretary DeVos and others offer a more pessimistic view, however, in highlighting that Title IX investigations may suppress the rights of the accused and may lead to an

\footnotetext{
${ }^{2}$ Other researchers have recently examined the impacts of females' participation in sports resulting from Title IX. Baker and Cornelson (2016) find little evidence of effects on the spatial skills associated with women's occupations. Schulkind (2017) finds that babies born to women with greater athletic opportunities as teenagers are healthier at birth.

${ }^{3}$ See Lindo, Siminski, and Swensen (2018) on the link between college party culture and sexual assault.
} 
atmosphere of sexual "paranoia” on campus (Kipnis, 2017). It is certainly important to consider how federal investigations may act as an agent for broader changes to institutions. Federal attention could intensify student- and/or university-led sexual violence prevention and response efforts, perhaps with negative unintended consequences along the lines that DeVos suggested. Federal investigations may also put pressure on administrators to improve the university in other ways, such as attempting to offset the negative publicity associated with the investigation with changes in an institution's marketing and outreach efforts.

In this paper, we bring together data from several sources in order to study the overall effects of Title IX investigations by OCR. We do so using event-study methods that quantify how these outcomes deviate from expected levels leading up to and following the opening of a federal investigation. Information on OCR's Title IX investigations is based on the Chronicle of Higher Education's Title IX Tracker database. We confirm that openings of investigations are salient using data on Google searches for college names combined with rape. We then use panel data from the Integrated Postsecondary Education Data System (IPEDS) and from the Council for Aid to Education's Voluntary Support of Education Survey (VSES) to evaluate the impacts on applications, enrollment, degree completion, and alumni giving.

We find no evidence federal Title IX investigations reduce students' interest in a university. Instead, we find evidence that these investigations increase freshman applications and enrollment, for both female and male students. Federal Title IX investigations appear to have no effect on student retention, as the enrollment of continuing students is unaffected. We also find no effects on rates of degree completion. Our analysis of VSES data suggests that federal Title IX investigations have no detectable effects on donations. Interestingly, these same data indicate that institutions respond to these investigations by soliciting donations from more alumni.

Though we are unable to determine the exact mechanisms underlying these results, the pattern of the estimates is informative. The evidence that OCR's Title IX investigations generate immediate increases in applications of both males and females in the short run suggests that investigations do not deter students from applying for admission, or that the number of deterred students is dwarfed by the number of additional students who become interested because of increased salience, changes at the institution, or intensified marketing efforts by the institution. The fact that we find similar effects for female and male students suggests that the primary mechanism is not gender-specific, so changes in safety, or perceptions about safety, are also 
unlikely to play a central role. This interpretation is further supported by our evidence that Title IX investigations do not affect persistence at the university. It seems that colleges and universities intensify their outreach efforts as a result of being under investigation, which is evident from our estimated effects on solicitations to alumni. This may explain why we do not find evidence of significant reductions in giving to universities resulting from investigations. Moreover, given that colleges and universities appear to intensify their outreach efforts directed at alumni, there is reason to believe that they may do similarly for prospective students. However, our interviews with admissions officers indicated that they did not. For this reason, we believe that direct effects of Title IX investigations on salience is the most plausible explanation for their surprising effects on student applications and enrollment.

Our use of the word "salience" here is in the same spirit as Tversky and Kahneman's (1974) description of "availability" or "retrievability." They point out that the ease with which something comes to mind may lead to behavioral biases. In our context, the publicity generated by a federal Title IX case could increase the likelihood that a school comes to mind when students form their consideration set. And this effect could dominate any negative effects associated with the associated with the investigation.

The idea that the salience of a college can have real effects is consistent with prior research. Indeed, Anderson (2017) documents that donations and applications increase as a result of as-good-as-random college football game outcomes. Moreover, this sort of behavior is consistent with evidence that many individuals do not make optimal decisions regarding college applications and college attendance. For example, a majority of very high-achieving low-income students do not apply to selective colleges despite the fact that they would often cost them less after financial aid (Hoxby and Avery 2013), though this can in part be overcome by providing assistance with the application process and information on financial aid (Bettinger et al. 2012; Hoxby and Turner 2013; Barr and Turner 2017).

\section{Background}

\section{A. Sexual Assault Incidence}

Campus sexual assault has long been a subject of study. In the first major study on sexual assault victimization among college women, Koss, Gidycz and Wisniewski (1987) estimated that more than one in four college women had experienced attempted or completed rape. While Koss 
et al. (1987) measured victimization since the age of 14, not just since date of college matriculation, their estimates were quite similar to later estimates focusing only on victimization during college. For example, the National College Women Sexual Victimization study estimated that $20-25 \%$ of women would experience attempted or completed rape while attending college (Fisher, Cullen \& Turner, 2000); Krebs, et al. (2007) found that approximately 20\% of college seniors at two large public universities experienced sexual assault; and Kilpatrick et al. (2007) found that $5.2 \%$ of a national sample of 2,000 college women experienced completed rape using force or incapacitation in the past academic year, which over four years would be comparable to earlier estimates. More recently, the Washington Post-Kaiser Family Foundation Survey, a nationally representative phone survey of over 1,000 current and recent undergraduates conducted in 2015, documented similar victimization rates to Krebs, et al. (2007) while the AAU Campus Survey on Sexual Assault and Sexual Misconduct, a web-based survey of over 150,000 students administered at 27 universities in 2015, estimated a rate of 23.1 percent female undergraduate students reporting experiencing sexual assault or sexual misconduct (Cantor, et al., 2015). Although these rates have been generally consistent, estimates of sexual victimization can sometimes be difficult to compare because studies vary in their reporting periods, survey response rates, and their measures of sexual victimization (Fedina, Holmes \& Backes, 2016).

\section{B. Policy Context Prior to the "Dear Colleague” Letter}

The history of federal legislation to protect college students from criminal victimization begins with the Clery Act of 1990. The main provision of Clery requires colleges and universities to make crime statistics publicly available and to issue timely warnings of any ongoing threats to the campus population (US Department of Education, 2016). Yet, institutions have a disincentive to encourage students to report, since publicly available crime statistics may affect public perceptions of the institution and future enrollment. Critics have described the Clery Act as symbolic rather than substantial (Fisher, Hartman, Cullen \& Turner, 2002). The statistics that colleges and universities report for Clery are not inclusive of all crimes involving students, because they are only required to report crimes that occurred on or near campus or campus property, even if those crimes were committed or perpetrated against individuals unaffiliated with the university. This means that reported data does not distinguish between dangerous campuses and dangerous cities in which colleges are situated. A further complication arises 
because of the general reluctance of students to report sexual assault to authorities (Fisher et al., 2000). As a result, higher sexual assault statistics may be indicators of a campus climate conducive to increasing student willingness to report assaults, rather than underlying victimization rates (Cantalupo, 2011; Palmer \& Alda, 2016).

The Violence Against Women Act (VAWA), first authorized in 1994 as part of the Violent Crime Control and Law Enforcement Act (H.R. 3355), supplemented federal law to protect students (and others) on college and university campuses (Dunn, 2013; Schroeder, 2013). In addition to granting funds to on-campus programs to prevent and respond to victimization, the law also requires colleges and universities to offer sexual assault prevention programs for all incoming students and new employees. In addition, the 2013 reauthorization of VAWA amended the Clery Act to outline several procedural requirements related to adjudication processes in cases of student victimization to assure transparency; a prompt, fair and impartial proceeding; and also confidentiality for the victim. ${ }^{4}$

\section{The "Dear Colleague Letter" and The Use of Title IX to Address Sexual Assault}

In 2011, the U.S. Department of Education's OCR released the DCL ${ }^{5}$ that clarified the requirements of Title IX in the context of sexual violence at all public and private schools, colleges and universities that receive federal financial assistance. Title IX is a civil rights law passed as part of the Higher Education Amendments of 1972 to assure equal access to education. The initial implementation of this law focused on female students' access to sports and equitable athletic facilities. Over time, the law was interpreted to include other forms of sex-specific discrimination that affect female students' equal access to education. The OCR is responsible for investigating any complaint that an educational institution violated Title IX.

The DCL clarified that Title IX required a prompt and equitable investigation if the school is aware of an allegation of sexual harassment or sexual violence. If a school "knows or reasonably should know" of an instance of sexual harassment or sexual violence, it was required to immediately complete a "prompt, thorough, and impartial" investigation. Any adjudication process was to use a preponderance of evidence standard, which is a lower burden of proof than the beyond a reasonable doubt standard used for sexual assault cases in the criminal justice

\footnotetext{
${ }^{4}$ See https://www.federalregister.gov/documents/2014/10/20/2014-24284/violence-against-women-act.

${ }^{5}$ See http://www2.ed.gov/about/offices/list/ocr/letters/colleague-201104.html.
} 
system. If the adjudication process resulted in a finding that sexual violence occurred, the institution was required to "take immediate action to eliminate the hostile environment, prevent its reoccurrence, and address its effects” (DCL, 2011, p.15). If a victim or the accused believed any of these steps were not followed adequately, she or he could elect to file a complaint with OCR within 180 days. If OCR determined the college or university did not respond promptly and equitably, that served as a potential indication that the institution violated Title IX. Schools found to be non-compliant could face fines, lose federal funding and be required to take steps to remedy or correct their response to sexual violence.

\section{Title IX and Public Awareness}

The OCR's action was largely in response to growing public attention to the issue of campus sexual assault and how it was being handled. In 2010, National Public Radio and the Center for Public Integrity released a series on failure by colleges to protect women from campus rape. Their investigations found that colleges rarely expelled those accused of sexual assault and prevention programs put the responsibility on women to prevent rape. They presented their findings directly to the Assistant Secretary for OCR, who committed to more aggressively address sexual violence on college campuses (NPR, 2010). More recent examples of public attention include the 2015 documentary film The Hunting Ground, which offered several survivors' perspectives of how their universities did not properly respond to their allegations of sexual assault, and follows two activists who began to teach their peers how to file a complaint with the OCR. The same year a widely read book on the handling of sexual violence cases by the University of Montana and the local police helped to further raise the public's awareness of the institutional protectionism and inadequate response that many students face when they report sexual violence to university administrators (Krakauer, 2015).

The OCR's increase in Title IX investigations has focused substantial attention on issues of climate and safety for female students. In the years after the DCL, each new investigation was widely covered in national news, especially at elite institutions, and the Chronicle of Higher Education has devoted special attention to each case. In May of 2014, for the first time ever, OCR made public the list of 55 higher educational institutions with open Title IX investigations 
related to sexual violence. As of May, 2018, 458 sexual assault investigations had been opened at American colleges and universities under Title IX. Of these, only 121 cases have been resolved. ${ }^{6}$

Unlike Clery, which provides general information about crime statistics, this increase in OCR Title IX investigations focused attention on sexual assault at specific institutions, how these schools handled victims' complaints and how they treated the accused. Consequently, OCR Title IX investigations may have caused real concern about school climate. These cases may have been seen as warning signs about the extent of sexual victimization on a given campus and the degree to which students' complaints are taken seriously and judiciously processed.

Of course, the actions of a federal department in Washington DC to announce investigations may be of little notice by prospective and current college students or their parents. We know of no reliable data on the awareness of these issues for representative students at colleges under investigation or elsewhere. For this reason, before examining the impacts on various university outcomes, we begin our analysis by evaluating the salience of these investigations using data on Google searches for college names combined with key words associated with sexual assault.

\section{Data}

Our data on Title IX investigations are based on the Title IX Tracker database, compiled by the Chronicle of Higher Education from Freedom of Information Act requests of the U.S. Department of Education. These data include the date on which the OCR determined that a complaint against an institution had merit and opened an investigation into its handling of a case of sexual violence. The first investigation in the Title IX Tracker database was opened in August of 2008. Our analysis uses data on all investigations that were opened between January of 2010 and July of 2014 to correspond to our sample of schools and outcome data described below.

As a means to assess the extent of public awareness of Title IX investigations, we compile data on topical search queries from Google Trends. Necessarily, if Title IX investigations have any effect on prospective or current students, knowledge about the investigations must extend beyond those directly involved. Google Trends provides a ready means to assess volume of search activity over time. We compiled these data by searching for the term "rape" and variations of the school's name for the schools that had a Title IX

\footnotetext{
${ }^{6}$ See http://projects.chronicle.com/titleix/.
} 
investigation opened between January of 2010 and July of $2017 .{ }^{7}$ For example, we searched for "Frostburg State University," as well as "Frostburg” and "Frostburg State," and "Pennsylvania State University” as well as "Penn State.” For each university for which the OCR announced a Title IX investigation, we generated a time series of monthly search volume, from January 2004 to June 2017.

To consider the effects of Title IX investigations on students, we use data from the U.S. Department of Education's Integrated Postsecondary Education Data System (IPEDS). IPEDS includes institutional characteristics and outcome data gathered from annual surveys of colleges and universities that participate in federal student financial aid programs. We restrict our attention to 4 year and beyond non-profit universities with non-specialized Carnegie Classifications. ${ }^{8}$ We also drop schools that are predominantly male or female, military schools and schools that experience more than a 25 percent change in enrollment from one year to the next. Finally, we limit our focus to universities that report female enrollment-a primary outcome of interest-in each year of our sample. The resulting sample includes 1,170 institutions reporting undergraduate female enrollment from 2002-2016 and slightly fewer schools reporting outcomes by age, new enrollees, and returning students. Of the 1,170 institutions, 80 experienced a Title IX investigation by OCR.

IPEDS data allow us to consider effects of Title IX investigations on undergraduate applications, admissions, and completions. We consider enrollment outcomes separately by gender, age, and status as a new or returning student. We initially focus on female enrollment outcomes, based on priors that their decisions may be more responsive to the issues surrounding these investigations.

We also use data from the Council for Aid to Education's (CAE) annual Voluntary Support of Education Survey (VSE) to consider effects of OCR Title IX investigations on alumni giving. These data are the primary source of data on philanthropic giving to U.S. colleges and universities and include voluntary giving from all colleges and universities willing to participate in the survey. As before, our sample includes investigations that were opened between January of

\footnotetext{
${ }^{7}$ Of the 94 schools under Title IX investigation for which we searched Google Trends, we found no search activity on the topic for eight small colleges: Cedarville College, Glenville State College, Hobart William Smith College, Kentucky Wesleyan, Northern New Mexico College, St. Mary’s College of Maryland, St. Thomas Aquinas College, and Samuel Merritt College.

${ }^{8}$ Consequently, we omit specialized schools, such as seminaries, yeshivas, schools of medicine or health professions, and art schools.
} 
2010 and July of 2014, and VSE data from 2002-2016. We use the same sample restrictions as our IPEDS sample, though there are far fewer institutions represented in the VSE sample. In total, our VSE sample includes 790 institutions, 65 of which experienced a Title IX investigation.

In Table 1 we present mean outcomes for the colleges and universities in our sample, overall and by whether a school had an OCR Title IX investigation during our sample period. Schools that come under federal investigation are, on average, much larger, more selective and have higher graduation rates. The average female undergraduate full-time enrollment was 5,080 at schools with federal investigations, compared to 2,448 for schools without investigations. Schools with investigations admit less than half of applicants, compared to 61 percent for other schools. ${ }^{9}$ Note, too, that BA completion rates are markedly higher for both men and women at schools that had OCR Title IX investigations. Finally, schools that were investigated had higher alumni giving rates than other schools (17 percent versus 13 percent) despite similar solicitation rates (85 percent versus 83 percent). All of these comparisons highlight the importance of controlling for systematic differences across schools in our analysis of the effects of Title IX investigations, which we discuss in the next section.

\section{Empirical Models}

To measure impacts of Title IX investigations, we generate indicators of whether a college or university had an investigation open in an academic year. We assign an investigation to an academic year if OCR notified the institution by July of that year. As such, we would classify a notice issued in June 2011 as occurring in the 2011-12 academic year. We recognize that an indicator variable of a case opened in an academic year is a crude way of estimating enrollment effects: it might take time for matriculating or prospective students to react or current students to transfer if an OCR Title IX investigation was a source of concern. Or, it could be that potentially mishandled cases of sexual violence that are brought to the U.S. Department of Education are sources of upset at the university-level before any Title IX investigation is launched. To capture these possibilities, we estimate models with both leading and lagging indicators of Title IX investigations.

\footnotetext{
${ }^{9}$ Relative SAT scores are another measure of selectivity. The 75th percentile of students' SAT scores at Title IX schools is a full standard deviation higher than other schools.
} 
Specifically, we estimate the impact of Title IX investigations on applications, enrollment, degree completion and alumni giving using models of the following type:

$$
y_{s, t}=\alpha_{s}+\theta_{s} t+\gamma_{t}+\sum_{b=-2}^{2} \delta_{b} \text { TitleIX } X_{s, t+b}+\epsilon_{s, t}
$$

where $y_{s, t}$ is an outcome variable associated with school $\mathrm{s}$ in year $\mathrm{t} ; \alpha_{s}$ and $\theta_{s} t$ are schoolspecific fixed effects and linear trends, respectively; $\gamma_{t}$ are year fixed effects; and TitleIX $X_{s, t+b}$ is a set of variables indicating leads and lags relative to the opening of an investigation. We include two leads to examine the evolution of outcomes leading up to an investigation and two lags to examine how the effects might vary over time. The omitted category is being three or more years prior to an investigation. Observations three or more years after an investigation is opened are not included in the analysis because there are too few such observations to reliably estimate the effects at longer lags since the beginning of an investigation. Thus, the coefficients of interest, $\delta_{b}$, measure how schools' outcomes change in the years before and after the opening of an investigation relative what is expected based on their pre-existing trend and relative to the changes from trend observed nationwide over the same time period. Where possible, we separately evaluate females and males. All standard errors are clustered at the school level.

\section{Results}

\section{A. Examining the Salience of Title IX Investigations}

Before presenting our main results, in this section we attempt to gain insight into the question of whether the Title IX investigations generate attention from individuals interested in a college. We do so using monthly panel data from Google Trends on searches for "rape" or "sexual assault" and the name of a college or university that came under Title IX investigation during the period we study. Google Trends provides data on search interest for a term on scale of 0 to 100 . The scale is normalized to the time period considered, so that 100 represents peak search activity for a given term compared to other searches at that time. We evaluate indices for both web searches and news searches.

The results of this analysis are shown in an event-study graph in Figure 1, which plots such search activity as a function of the number of months before and after the opening of a Title 
IX investigation, adjusted for school-specific fixed effects and linear trends in addition to yearby-month fixed effects. Month 0 refers to the month when OCR opened an investigation of a given college or university. If the estimates were consistently at zero, it would indicate that there were no systematic deviations from school-specific trends in searches for "rape" combined with the school name around the time an investigation was opened. Both the estimates for web searches (Panel A) and for news searches (Panel B) provide some evidence that search activity starts to deviate (upwards) from trend in advance of the opening of an investigation; however, the estimates are never statistically significant at conventional levels. Both panels show clear evidence that search activity is significantly elevated above trend in the month an investigation is open, and perhaps also the month before. Search activity then quickly returns to trend after the opening of the investigation.

\section{B. Main Results}

In Table 2, we present estimates of the impacts of Title IX investigations on a variety of enrollment outcomes for undergraduate female students. These are the natural log of total fulltime female enrollment; first-year full-time (FYFT) enrollment; continuing and transfer enrollment; and then full-time enrollment by age. The top and bottom panels differ in how we model underlying time trends, and highlight the importance of controlling flexibly for institutionspecific trends. In the top panel where we do not allow for any such trends, the estimates suggest some significant negative impacts of investigations before they are actually opened by OCR. While it's possible that events leading up to investigations could affect enrollment, in this case these statistically significant estimates are entirely an artifact of different underlying trends for schools that were the subject of Title IX investigations. As we show in the lower panel, once we augment the specification to include institution-specific linear trends, these effects disappear. ${ }^{10}$ All of the results discussed throughout the remainder of this paper are based on specifications including such trends.

The results in the lower panel of Table 2 indicate female enrollment is increased by Title IX investigations. In particular, they indicate that female enrollment is increased by 2.4 percent one year after enrollment could plausibly be affected (significant at the ten percent level) and 3.2

\footnotetext{
${ }^{10}$ The main results here differ from those of an early paper on this topic (Marcotte and Palmer, 2016) in part because the empirical models in that paper did not include institution-specific trends. In the current paper we also use data from a longer panel, and have dropped observations with unusually large intertemporal changes in enrollment.
} 
percent two years after enrollment could plausibly be affected (significant at the five percent level). These effects are driven by impacts on female first-time-first-year (FYFT) enrollment, where the estimated effects are larger in magnitude (Column 2). Specifically, our estimates indicate that female FYFT enrollment is increased by 3.6 percent one year after enrollment could plausibly be affected (significant at the ten percent level) and 4.7 percent two years after enrollment could plausibly be affected (significant at the five percent level). The estimated effects on female continuing enrollment are generally close to zero (Column 3). The estimated effects on enrollment by females transferring in are imprecise (Column 4).

In Table 3, we present the results of our analysis of the effects on undergraduate male enrollment. These results indicate that male enrollment is also increased by OCR Title IX investigations, again driven by FTFY students. Moreover, they suggest that the effects are larger and more immediate for males than females. Specifically, our estimates indicate that male FYFT enrollment is increased by 4.2 percent in the first-year enrollment could plausibly be affected, 5.6 percent the following year, and 7.4 percent the following year. All of these estimates are significant at the five percent level.

As another way of investigating the effects of OCR Title IX investigations on students' interest in schools, we also estimate the impacts on applications. The results of this analysis, shown in Table 4 indicate that Title IX investigations lead to significant increases in applications in the first year in which they could plausibly be affected by the opening of an investigation and that these effects grow over time. Specifically, our estimates indicate that female applications are increased by 7.2 percent in the first year, 9.4 percent the following year, and 13.8 percent the following year. Our estimates indicate that male applications are increased by 8.7 percent in the first year, 11.2 percent the following year, and 15.1 percent the following year. All of these estimates are significant at the five percent level.

In Appendix Table A1 we round out the picture regarding FTFY students by showing the estimated effects on admissions. The estimated effects are always positive, suggesting that the increases in applications are accompanied by increases in admissions, but these estimates are never statistically significant.

We now turn to degree completion, which we view as a rough measure of student persistence. One might expect the circumstances surrounding a high profile OCR Title IX investigation to disrupt students' academic progress. This might occur if it raises students' fear 
for their safety or if it affects student trust of the administration. Or a student may focus less on academic work and more on campus climate issues, or redress for victims of sexual assault. Necessarily, though, completion and graduation rates are lagging indicators of student progress. In Table 5 we present the estimated effects on degrees awarded and completion rates separately for females and males. These estimates are never statistically significant at the five percent level.

Finally, in Table 6 we show the estimated effects on alumni giving using data from the Council for Aid to Education's Voluntary Support of Education Survey (VSES), which is the most comprehensive data set available on such giving. Specifically, in this table we report the estimated effects on the percent of alumni giving and the percent solicited. These estimates indicate that OCR Title IX investigations cause schools to intensify their efforts to solicit donations from alumni in the years just after such an investigation is opened. In particular, they indicate that the federal investigation causes schools to increase the number solicited by five percentage points in the two years following the opening of an investigation. The estimated effects on the percent of alumni giving are not statistically significant and are close to zero. If we assume that additional efforts to solicit donations from alumni are effective, these results on solicitations and donations jointly imply that schools are able to fully make up an expected net reduction in donors by soliciting more alumni. To summarize, we find little evidence that the attention brought on by an OCR Title IX investigation affects alumni giving, though this may be in part because schools increase solicitations in response to such investigations.

We have also investigated the impacts on the log of dollars given to capital and current operations, in addition to the log of average donations. Unfortunately, the estimates are far too imprecise to be able to rule out large negative or large positive effects. Likewise, we find very imprecise estimates when we focus on giving to athletics operations. For the interested reader, these estimates are reported in Appendix Table A2.

\section{Discussion and Investigation of Mechanisms}

The results of our analyses naturally raise questions about the why OCR Title IX investigations lead to increased interest from prospective students. Although we cannot answer this question definitively, in this section we highlight what can be gleaned from the pattern of estimates we presented previously and from interviews we conducted. 


\section{A. Insights from the Pattern of Estimates}

Because the impacts on applications are immediate, it is unlikely that they are driven by major positive changes at the schools under investigation-it would likely take time to implement such changes and for prospective students to learn about them. And because these immediate effects on applications are present for both males and females, it is unlikely that they are driven by impacts on perceptions about school safety, which we would expect to be more important for female prospective students than male prospective students. It seems more likely that the effects are driven by salience. In particular, the attention generated by an OCR Title IX investigation - though negative-may cause the school to enter the consideration sets of more students when they are choosing where to apply. And this may naturally lead to increases in enrollment. Interestingly, we find that the immediate positive effect on applications translates into an immediate positive effect on first time first year enrollment for males, but not for females. This is consistent with the idea of a recall heuristic, or "availability" heuristic (Tversky and Kahneman, 1974), which biases females' decisions about where to apply but not where to attend in the short run.

\section{B. Insights from Interviews}

We also conducted interviews with admissions officers (e.g., Director of Admissions, Dean of Admissions, VP for Enrollment Management, etc.) in order to gain further insight into the mechanisms underlying our main results. Specifically, we sent emails to such officers at all 37 of the schools who had a Title IX investigation opened prior to 2013, which are the schools that contribute to the estimated effects for all leads and lags. ${ }^{11}$ This email requesting an interview explained that we were "researching what, if any, impact a Title IX investigation may have on applications or enrollment” and that the conversation would be confidential. If our initial contact suggested we contact another individual at the school, we did so. In addition, we sent a second email to individuals who did not respond to the initial email. In total, we were able to conduct five interviews as a result of these efforts. All five of these admissions officers reported that Title IX investigations raised no concerns about negative impacts on applications to their school. One stated that this was because he thought it was clear that the university had not done anything

\footnotetext{
${ }^{11}$ Schools with investigations opened later contribute to the estimated effects as well, but only schools with investigations opened prior to 2013 contribute to the estimated effects " $t+2$ " or the third year following the opening of an investigation.
} 
wrong. Another explained that his school was getting more and more applications each year. A third reported that students perceive sexual assault to be common on college campuses, so she did not believe the attention to her school signaled any unique risk to prospective students. Given these views, it is thus not surprising that the same admissions officers reported that little extra was done to try to increase admissions after the Title IX investigations were opened. One admissions officer noted that their school made a public response to being under investigation through typical media channels. Another mentioned reminding everyone of resources available on campus about security and safety education initiatives. As a whole, this limited set of interviews supports the idea that a salience mechanism explains why Title IX investigations increase interest from prospective students, rather than schools ramping up their efforts to recruitment efforts.

\section{Conclusion}

At a time of heightened attention to issues of sexual assault and harassment, there is real debate about the role of federal policy in overseeing how U.S. colleges and universities protect their students. The expansion (and recent contraction) of the investigatory role of the OCR has been the most important recent change in federal policy in this domain. We study the impacts of the OCR's Title IX investigations on a variety of measures important to college administrators and education researchers.

We find no evidence that federal Title IX investigations negatively affect students' interest in a school. Indeed, we find that they increase applications for admission from both males and females. Moreover, they increase freshman enrollment for both males and females, though this increase is immediate for males and only shows up one to two years later for females. This pattern of results is consistent with the idea that salience effects generated by Title IX investigations dominate the effects of the negative publicity associated with the investigations. An important implication of our results is that federal investigations and campus reviews of how sexual assault allegations are handled do not affect university applications and enrollments. We can neither offer assessment of the procedural improvements these reviews might elicit, nor any recourse they provide to petitioners. However, our findings should reassure college administrators that efforts to improve processes for reviewing accusations of sexual assault and providing remedy to victims does not come at the expense of broader university goals. Indeed 
colleges could do better to inform students about their rights under federal law, the remedies available to them and to make their processes more transparent (Richards, 2016). A recent study of students at 27 universities found that $63 \%$ of students thought it was likely that a sexual assault report would be taken seriously by campus officials; only $49 \%$ of students thought that campus officials would conduct a fair investigation if sexual assault were reported; and only $44 \%$ of students thought that an investigation would result in any action against the offender (Cantor, et al., 2015).

\section{REFERENCES}

Anderson, M. L. (2017). The Benefits of College Athletic Success: An Application of the Propensity Score Design with Instrumental Variables. Review of Economics and Statistics, 99 (1), 119-134.

Aud, S., Hussar, W., Kena, G., Bianco, K., Frohlich, L., Kemp, J., Tahan, K. (2011). The Condition of Education 2011 (NCES 2011-033). U.S. Department of Education, National Center for Education Statistics. Washington, DC: U.S. Government Printing Office.

Baker, M. and Cornelson, K. (2016). Title IX and the Spatial Content of Female EmploymentOut of the Lab and into the Labor Market. NBER Working Paper no. 22641.

Barr, A. and Turner, S. (forthcoming). A Letter and Encouragement: Does Information Increase Post-Secondary Enrollment of UI Recipients? American Economic Journal: Economic Policy, forthcoming.

Bettinger, E. P., Long, B. T., Oreopoulos, P. and Sanbonmatsu, L. (2012). The Role of Application Assistance and Information in College Decisions: Results from the H\&R Block Fafsa Experiment. The Quarterly Journal of Economics, 127(3), 1205-1242.

Campbell, R., Dworkin, E., \& Cabral, G. (2009). An ecological model of the impact of sexual assault on women's mental health. Trauma, Violence, \& Abuse.

Cantalupo, N. C. (2011). Burying our heads in the sand: lack of knowledge, Knowledge avoidance and the persistent problem of campus peer sexual violence. Loyola University Chicago Law Journal, 43, 205.

Cantor, D., Fisher, B., Chibnall, S., Townsend, R., Lee, H., Bruce, C., \& Thomas, G. (2015). Report on the AAU Campus Climate Survey on Sexual Assault and Sexual Misconduct. Rockville, MD: Westat. 
Center for Public Integrity. 2010.

https://www.publicintegrity.org/2010/02/24/4360/lack-consequences-sexual-assault

Chronicle of Higher Education. 2018. Retrieved from https://projects.chronicle.com/titleix.

Fedina, L., Holmes, J. L., \& Backes, B. L. (2016). Campus Sexual Assault A Systematic Review of Prevalence Research From 2000 to 2015. Trauma, Violence, \& Abuse, 1524838016631129.

Dunn, L. L. (2013). Addressing Sexual Violence in Higher Education: Ensuring Compliance with the Clery Act, Title IX and VAWA. Geo. J. Gender \& L., 15, 563.

Fisher, B. S., Cullen, F. T., \& Turner, M. G. (2000). The Sexual Victimization of College Women. Research Report.

Hoxby, Caroline and Christopher Avery. 2013. "The Missing "One-Offs": The Hidden Supply of High-Achieving, Low-Income Students," Brookings Papers on Economic Activity, pages $1-65$.

Hoxby, C. and Turner, S. (2013). Expanding College Opportunities for High-Achieving. Low Income Students. SIEPR Discussion Paper 12-014.

Kipnis, L. (2017). Unwanted Advances: Sexual Paranoia Comes to Campus. Harper.

Richards, T. N. (2016). An Updated Review of Institutions of Higher Education's Responses to Sexual Assault Results from a Nationally Representative Sample. Journal of Interpersonal Violence, 1-30.

Koss, M. P., Gidycz, C. A., \& Wisniewski, N. (1987). The scope of rape: incidence and prevalence of sexual aggression and victimization in a national sample of higher education students. Journal of consulting and clinical psychology, 55(2), 162.

Krakauer, J. (2015). Missoula: Rape and the justice system in a college town. New York, NY: Doubleday.

Krebs, C. P., Lindquist, C. H., Warner, T. D., Fisher, B. S., \& Martin, S. L. (2007). The campus sexual assault (CSA) study: Final report. Washington, DC: National Institute of Justice, US Department of Justice.

Kruttschnitt, C., Kalsbeek, W.D., \& House, C.C. (2014). Estimating the incidence of rape and sexual assault. Washington, DC: National Research Council.

Kilpatrick, D. G., Resnick, H. S., Ruggiero, K. J., Conoscenti, L. M., \& McCauley, J. (2007). Drug-facilitated, incapacitated, and forcible rape: A national study. National Criminal Justice Reference Service. 
Lindo, Jason M., Peter Siminski, and Isaac D. Swensen. 2018. "College Party Culture and Sexual Assault." American Economic Journal: Applied Economics, 10 (1): 236-65.

Marcotte, Dave E., and Jane E. Palmer. 2016. “Sexual Violence, Title IX and Women’s College Enrollment.” IZA Discussion Paper 10345.

McMahon, S., Stepleton, K., O’Connor, J. \& Cusano, J. (2015). \#iSPEAK student experiences, attitudes and beliefs about sexual violence. New Brunswick, NJ: Rutgers University, School of Social Work, Center on Violence Against Women and Children.

National Public Radio. (2010). Seeking Justice for Campus Rapes. Washington DC: National Public Radio with the Center for Public Integrity. Retrieved from http://www.npr.org/series/124073905/seeking-justicefor-campus-rapes.

Richards, T. \& Kafonek, K. (2016). Reviewing state legislative agendas regarding sexual assault in higher education: Proliferation of best practices and points of caution. Feminist Criminology, 11(1), 91-129.

Schroeder, L. P. (2013). Cracks in the ivory tower: How the Campus Sexual Violence Elimination Act can protect students from sexual assault. Loy. U. Chi. LJ, 45, 1195.

Schulkind, L. (2017). Getting a Sporting Chance: Title IX and the Intergenerational Transmission of Health. Health Economics, 26(2), 1583-1600.

Tversky, Amos, and Daniel Kahneman. 1974. "Judgement under Uncertainty: Heuristics and Biases,” Science, 27, 1124-31.

U.S. Department of Education. (2016). The Handbook for Campus Safety and Security Reporting, 2016 Edition. Washington, D.C.: Office of Postsecondary Education. Retrieved from http://www.ed.gov/admins/lead/safety/campus.html.

US Department of Justice, National Institute of Justice. (2008). Measuring Frequency. Retrieved from www.nij.gov/topics/crime/rape-sexual-violence/campus/pages/measuring.aspx. 
Figure 1

Google Trends Search Index for Rape and "College Name" For Schools With Investigations

\section{Panel A: Web Searches}

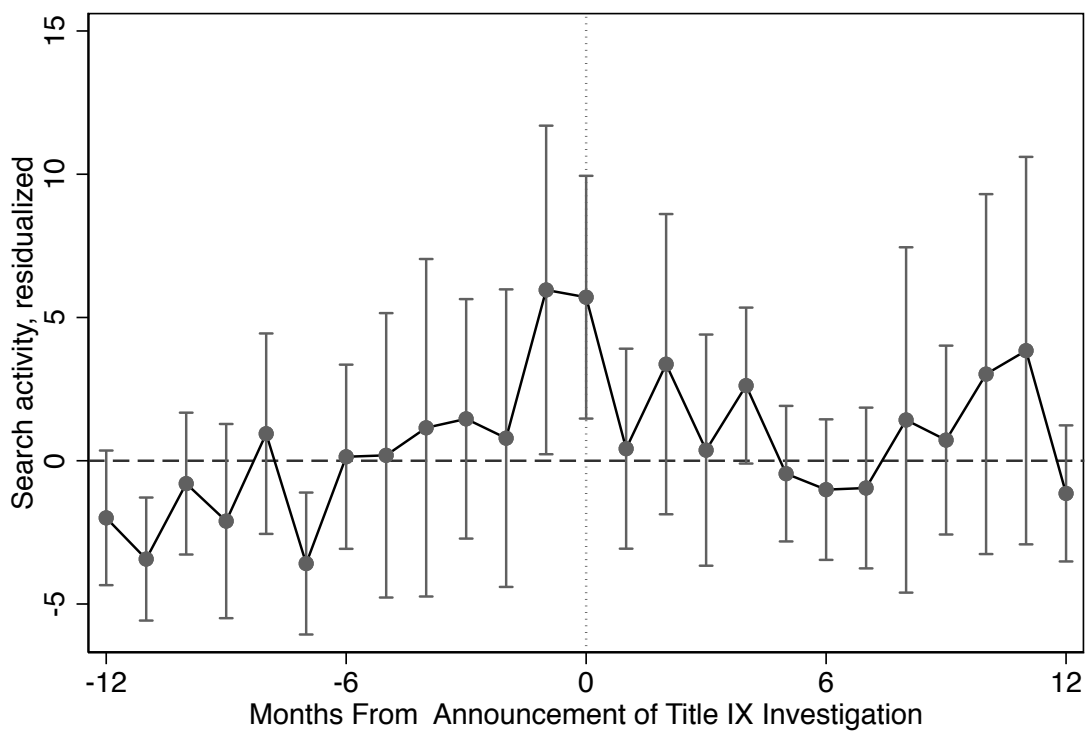

Panel B: News Searches

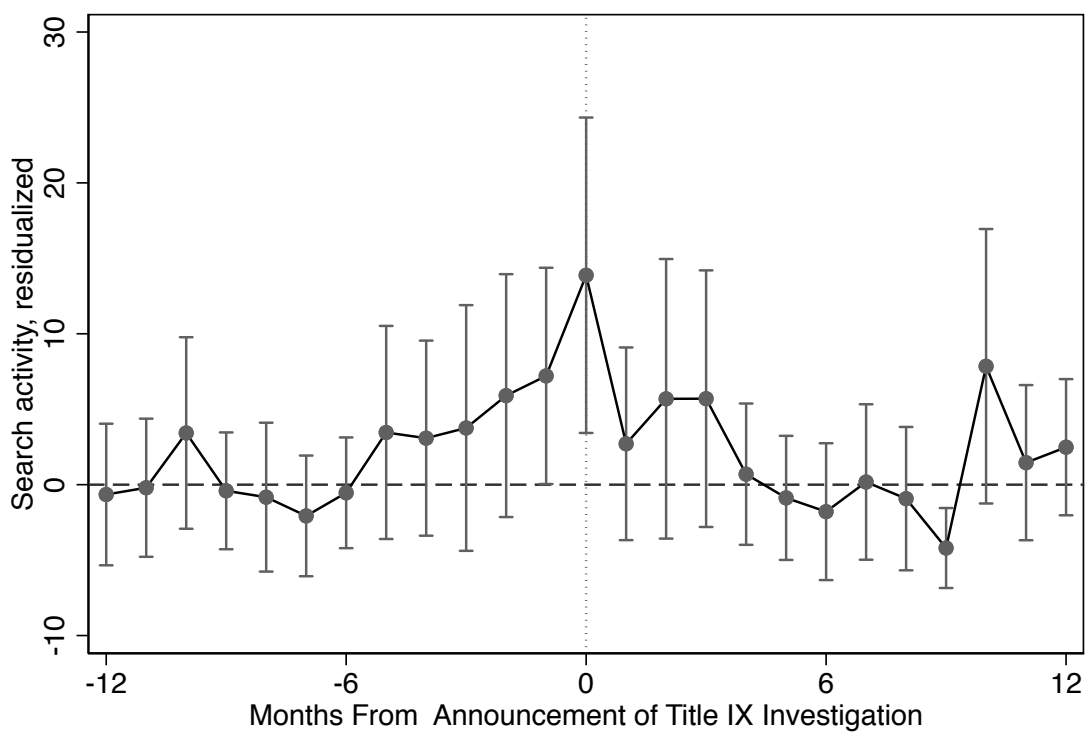

Notes: Estimates are based on google trends data from January 2004 - June 2017. Estimates are based on a regression model including the indicator variables for the shown leads and lags of the opening of a Title IX investigation, school-specific fixed effects and linear trends and month-by-year fixed effects in addition to. 
Table 1

Outcomes for IPEDS Analysis Sample

\begin{tabular}{|c|c|c|c|c|c|}
\hline & \multicolumn{3}{|c|}{ Mean } & \multicolumn{2}{|c|}{ Observations } \\
\hline & All & Investigated & Not investigated & Schools & School-years \\
\hline \multicolumn{6}{|c|}{ Undergraduate Full-time Enrollment } \\
\hline Female Total & 2638 & 5080 & 2448 & 1099 & 16295 \\
\hline Male Total & 2207 & 4675 & 2015 & 1099 & 16295 \\
\hline Female, First-Time & 570 & 1129 & 526 & 1096 & 16228 \\
\hline Male, First-Time & 473 & 1005 & 432 & 1096 & 16228 \\
\hline Female, Continuing & 1923 & 3731 & 1785 & 1096 & 10839 \\
\hline Male, Continuing & 1627 & 3505 & 1483 & 1096 & 10839 \\
\hline Female, Transfers In & 206 & 286 & 200 & 1095 & 10249 \\
\hline Male, Transfers In & 177 & 277 & 170 & 1095 & 10249 \\
\hline \multicolumn{6}{|l|}{ Applications } \\
\hline Female & 3087 & 7101 & 2760 & 1063 & 15313 \\
\hline Male & 2436 & 6054 & 2140 & 1063 & 15309 \\
\hline \multicolumn{6}{|l|}{ Admissions } \\
\hline Female & 1838 & 3357 & 1714 & 1063 & 15310 \\
\hline Male & 1396 & 2756 & 1285 & 1063 & 15304 \\
\hline \multicolumn{6}{|l|}{ Degrees Awarded } \\
\hline Female & 1386 & 2774 & 1275 & 1092 & 15215 \\
\hline Male & 1028 & 2334 & 924 & 1092 & 15215 \\
\hline \multicolumn{6}{|l|}{ 5-Year Completion Rate } \\
\hline Female & 0.54 & 0.71 & 0.53 & 1087 & 14919 \\
\hline Male & 0.46 & 0.65 & 0.45 & 1087 & 14919 \\
\hline \multicolumn{6}{|l|}{ Voluntary Giving Outcomes } \\
\hline Percent of Alumni that Gave & 14 & 17 & 13 & 872 & 9804 \\
\hline Percent of Alumni Solicited & 83 & 85 & 83 & 872 & 9804 \\
\hline
\end{tabular}

Notes: Data on enrollment, applications, admissions, degrees awarded, and 5-year completion rates are based on U.S. Department of Education's Integrated Postsecondary Education Data System, 2002-2016. Data on voluntary giving are from the Council for Aid to Education's annual Voluntary Support of Education Survey, 2002-2016. Information on schools investigated for Title IX violations are based on the Chronicle of Higher Education's Title IX Tracker database. 
Table 2

Estimated Effects of Title IX Investigations on Undergraduate Female Enrollment

\begin{tabular}{|c|c|c|c|c|}
\hline & (1) & $(2)$ & $(3)$ & $(4)$ \\
\hline Student Type: & All & 1st time/year & Continuing & Transfer In \\
\hline \multicolumn{5}{|c|}{ Panel A: Without school-specific trends } \\
\hline Title IX year - 2 & $\begin{array}{c}-0.016^{* *} \\
(0.007)\end{array}$ & $\begin{array}{c}-0.034^{* *} \\
(0.015)\end{array}$ & $\begin{array}{c}0.004 \\
(0.006)\end{array}$ & $\begin{array}{l}-0.016 \\
(0.022)\end{array}$ \\
\hline Title IX year - 1 & $\begin{array}{l}-0.014 \\
(0.010)\end{array}$ & $\begin{array}{c}-0.030^{* *} \\
(0.015)\end{array}$ & $\begin{array}{c}0.005 \\
(0.009)\end{array}$ & $\begin{array}{l}-0.016 \\
(0.028)\end{array}$ \\
\hline Title IX year & $\begin{array}{l}-0.010 \\
(0.012)\end{array}$ & $\begin{array}{l}-0.021 \\
(0.018)\end{array}$ & $\begin{array}{c}0.007 \\
(0.011)\end{array}$ & $\begin{array}{c}0.007 \\
(0.031)\end{array}$ \\
\hline Title IX year + 1 & $\begin{array}{l}-0.009 \\
(0.013)\end{array}$ & $\begin{array}{l}-0.015 \\
(0.018)\end{array}$ & $\begin{array}{c}0.008 \\
(0.013)\end{array}$ & $\begin{array}{c}0.001 \\
(0.034)\end{array}$ \\
\hline Title IX year +2 & $\begin{array}{l}-0.014 \\
(0.019)\end{array}$ & $\begin{array}{l}-0.026 \\
(0.026)\end{array}$ & $\begin{array}{c}0.003 \\
(0.017)\end{array}$ & $\begin{array}{c}0.002 \\
(0.041)\end{array}$ \\
\hline Observations & 16295 & 16228 & 10838 & 10236 \\
\hline Clusters & 1099 & 1096 & 1096 & 1095 \\
\hline \multicolumn{5}{|c|}{ Panel B: With school-specific trends } \\
\hline Title IX year - 2 & $\begin{array}{c}0.005 \\
(0.007)\end{array}$ & $\begin{array}{c}-0.003 \\
(0.014)\end{array}$ & $\begin{array}{c}-0.002 \\
(0.008)\end{array}$ & $\begin{array}{l}-0.015 \\
(0.030)\end{array}$ \\
\hline Title IX year - 1 & $\begin{array}{c}0.010 \\
(0.010)\end{array}$ & $\begin{array}{c}0.007 \\
(0.015)\end{array}$ & $\begin{array}{l}-0.002 \\
(0.013)\end{array}$ & $\begin{array}{l}-0.012 \\
(0.036)\end{array}$ \\
\hline Title IX year & $\begin{array}{c}0.018 \\
(0.013)\end{array}$ & $\begin{array}{c}0.022 \\
(0.017)\end{array}$ & $\begin{array}{l}-0.001 \\
(0.017)\end{array}$ & $\begin{array}{c}0.016 \\
(0.048)\end{array}$ \\
\hline Title IX year +1 & $\begin{array}{c}0.024^{*} \\
(0.014)\end{array}$ & $\begin{array}{c}0.036^{*} \\
(0.019)\end{array}$ & $\begin{array}{l}-0.000 \\
(0.021)\end{array}$ & $\begin{array}{c}0.012 \\
(0.058)\end{array}$ \\
\hline Title IX year +2 & $\begin{array}{c}0.032^{* *} \\
(0.015)\end{array}$ & $\begin{array}{c}0.047^{* *} \\
(0.023)\end{array}$ & $\begin{array}{c}0.010 \\
(0.024)\end{array}$ & $\begin{array}{c}0.054 \\
(0.071)\end{array}$ \\
\hline Observations & 16295 & 16228 & 10838 & 10236 \\
\hline Clusters & 1099 & 1096 & 1096 & 1095 \\
\hline University FE & yes & yes & yes & yes \\
\hline Year FE & yes & yes & yes & yes \\
\hline
\end{tabular}

Notes: "Title IX year" refers to the first year outcomes are measured following the opening of a Title IX investigation. Regression models evaluate the natural log of the outcome variables, which are based on U.S. Department of Education's Integrated Postsecondary Education Data System data 2012-2016. Information on the timing of the Title IX investigations are based on the Chronicle of Higher Education's Title IX Tracker database. School-year observations more than two years following the opening of an investigation are not used in the analysis. Standard errors, clustered on schools, are shown in parentheses.

$*, * *$, and ${ }^{* * *}$ indicate statistical significance at the ten, five, and one percent levels, respectively. 
Table 3

Estimated Effects of Title IX Investigations on Undergraduate Male Enrollment

\begin{tabular}{|c|c|c|c|c|}
\hline & $(1)$ & $(2)$ & $(3)$ & $(4)$ \\
\hline Student Type: & All & 1st time/year & Continuing & Transfer In \\
\hline Title IX year - 2 & $\begin{array}{c}0.001 \\
(0.006)\end{array}$ & $\begin{array}{c}0.009 \\
(0.013)\end{array}$ & $\begin{array}{l}-0.004 \\
(0.009)\end{array}$ & $\begin{array}{c}0.001 \\
(0.029)\end{array}$ \\
\hline Title IX year - 1 & $\begin{array}{c}0.008 \\
(0.009)\end{array}$ & $\begin{array}{c}0.026 \\
(0.016)\end{array}$ & $\begin{array}{c}0.002 \\
(0.013)\end{array}$ & $\begin{array}{l}-0.020 \\
(0.044)\end{array}$ \\
\hline Title IX year & $\begin{array}{l}0.017 \\
(0.011)\end{array}$ & $\begin{array}{c}0.042^{* *} \\
(0.017)\end{array}$ & $\begin{array}{c}0.007 \\
(0.016)\end{array}$ & $\begin{array}{l}-0.005 \\
(0.056)\end{array}$ \\
\hline Title IX year + 1 & $\begin{array}{l}0.028^{*} \\
(0.014)\end{array}$ & $\begin{array}{c}0.056^{* * *} \\
(0.021)\end{array}$ & $\begin{array}{c}0.018 \\
(0.020)\end{array}$ & $\begin{array}{c}0.008 \\
(0.067)\end{array}$ \\
\hline Title IX year +2 & $\begin{array}{l}0.033^{*} \\
(0.017)\end{array}$ & $\begin{array}{c}0.074^{* * *} \\
(0.024)\end{array}$ & $\begin{array}{c}0.030 \\
(0.025)\end{array}$ & $\begin{array}{c}0.037 \\
(0.080)\end{array}$ \\
\hline Observations & 16292 & 16222 & 10839 & 10234 \\
\hline Clusters & 1099 & 1096 & 1096 & 1095 \\
\hline University FE & yes & yes & yes & yes \\
\hline Year FE & yes & yes & yes & yes \\
\hline University-specific linear trends & yes & yes & yes & yes \\
\hline
\end{tabular}

Notes: See Table 2.

$*, * *$, and $* * *$ indicate statistical significance at the ten, five, and one percent levels, respectively. 
Table 4

Estimated Effects of Title IX Investigations on Undergraduate Applications

\begin{tabular}{lcc}
\hline \hline & $(1)$ & $(2)$ \\
& $\begin{array}{c}\text { Female } \\
\text { Applications }\end{array}$ & $\begin{array}{c}\text { Male } \\
\text { Applications }\end{array}$ \\
\hline Title IX year - 2 & 0.011 & 0.025 \\
& $(0.019)$ & $(0.020)$ \\
Title IX year - 1 & 0.021 & 0.039 \\
& $(0.023)$ & $(0.027)$ \\
Title IX year & $0.072^{* *}$ & $0.087^{* *}$ \\
& $(0.030)$ & $(0.036)$ \\
Title IX year +1 & $0.094^{* *}$ & $0.112^{* * *}$ \\
& $(0.037)$ & $(0.043)$ \\
Title IX year +2 & $0.138^{* * *}$ & $0.151^{* *}$ \\
& $(0.053)$ & $(0.060)$ \\
Observations & 15313 & 15303 \\
Clusters & 1063 & 1063 \\
\hline University FE & & \\
Year FE & yes & yes \\
University-specific linear trends & yes & yes \\
\hline \hline
\end{tabular}

Notes: See Table 2.

${ }^{*},{ }^{* *}$, and ${ }^{* * *}$ indicate statistical significance at the ten, five, and one percent levels, respectively. 
Table 5

Estimated Effects of Title IX Investigations on Undergraduate Completion

\begin{tabular}{lcccc}
\hline \hline & $(1)$ & $(2)$ & $(3)$ & $(4)$ \\
& $\begin{array}{c}\text { Female } \\
\text { Degrees }\end{array}$ & $\begin{array}{c}\text { Male } \\
\text { Degrees }\end{array}$ & $\begin{array}{c}\text { Female } \\
\text { Completion } \\
\text { Rates }\end{array}$ & $\begin{array}{c}\text { Male } \\
\text { Completion } \\
\text { Rates }\end{array}$ \\
& & & & \\
& & & 0.007 & 0.001 \\
Title IX year - 2 & -0.009 & $-0.023^{*}$ & $0.009)$ \\
Title IX year - 1 & $(0.010)$ & $(0.012)$ & $(0.009)$ & $(0.009)$ \\
Title IX year & -0.001 & -0.019 & 0.008 & 0.008 \\
& $(0.013)$ & $(0.013)$ & $(0.010)$ & $(0.011)$ \\
Title IX year +1 & -0.003 & -0.027 & 0.009 & 0.007 \\
& $(0.017)$ & $(0.017)$ & $(0.012)$ & $(0.011)$ \\
Title IX year +2 & -0.022 & -0.029 & 0.007 & 0.010 \\
& $(0.027)$ & $(0.019)$ & $(0.017)$ & $(0.019)$ \\
Observations & -0.042 & $-0.056^{*}$ & 0.005 & 0.010 \\
Clusters & $(0.027)$ & $(0.031)$ & $(0.019)$ & $(0.020)$ \\
& 15215 & 15210 & 14914 & 14884 \\
University FE & 1092 & 1092 & 1087 & 1087 \\
Year FE & & & & yes \\
University-specific linear trends & yes & yes & yes & yes \\
& yes & yes & yes & yes \\
\hline \hline
\end{tabular}

Notes: We do not take the natural log of completion rates for this analysis, as we do for the outcomes considered in prior tables. For additional notes, see Table 2.

$*, * *$, and ${ }^{* * *}$ indicate statistical significance at the ten, five, and one percent levels, respectively. 
Table 6

Estimated Effects of Title IX Investigations on Alumni Giving

\begin{tabular}{lcc}
\hline \hline & $(1)$ & $(2)$ \\
& Percent Giving & Percent Solicited \\
\hline Title IX year - 2 & -0.008 & 2.432 \\
& $(0.228)$ & $(1.820)$ \\
Title IX year - 1 & 0.295 & 1.378 \\
& $(0.321)$ & $(2.069)$ \\
Title IX year & -0.039 & $4.979^{*}$ \\
Title IX year +1 & $(0.477)$ & $(2.639)$ \\
Title IX year +2 & -0.030 & $5.811^{* *}$ \\
& $(0.540)$ & $(2.939)$ \\
Observations & 0.184 & -0.937 \\
Clusters & $(0.676)$ & $(4.386)$ \\
& 9086 & 9086 \\
University FE & 790 & 790 \\
Year FE & & yes \\
University-specific linear trends & yes & yes \\
\hline \hline
\end{tabular}

Notes: "Title IX year" refers to the first year outcomes are measured following the opening of a Title IX investigation. Data on voluntary giving are from the Council for Aid to Education's annual Voluntary Support of Education Survey, 2002-2016. Information on the timing of the Title IX investigations are based on the Chronicle of Higher Education's Title IX Tracker database. School-year observations more than two years following the opening of an investigation are not used in the analysis. Standard errors, clustered on schools, are shown in parentheses.

$*, * *$, and ${ }^{* * *}$ indicate statistical significance at the ten, five, and one percent levels, respectively. 


\section{Appendix}

Table A1

Estimated Effects of Title IX Investigations on Undergraduate Admissions

\begin{tabular}{lcc}
\hline \hline & $(1)$ & $(2)$ \\
& $\begin{array}{c}\text { Female } \\
\text { Admissions }\end{array}$ & $\begin{array}{c}\text { Male } \\
\text { Admissions }\end{array}$ \\
\hline Title IX year - 2 & 0.010 & 0.017 \\
& $(0.014)$ & $(0.016)$ \\
Title IX year - 1 & 0.003 & 0.017 \\
& $(0.017)$ & $(0.022)$ \\
Title IX year & 0.028 & 0.045 \\
& $(0.024)$ & $(0.028)$ \\
Title IX year +1 & 0.044 & 0.040 \\
Title IX year +2 & $(0.031)$ & $(0.035)$ \\
& 0.070 & 0.062 \\
Observations & $(0.043)$ & $(0.045)$ \\
Clusters & 15310 & 15300 \\
& 1063 & 1063 \\
\hline University FE & & \\
Year FE & yes & yes \\
University-specific linear trends & yes & yes \\
\hline \hline
\end{tabular}

Notes: See Table 2.

$*, * *$, and ${ }^{* * *}$ indicate statistical significance at the ten, five, and one percent levels, respectively. 
Table A2

Estimated Effects of Title IX Investigations on Alumni Giving

\begin{tabular}{|c|c|c|c|c|c|}
\hline & $(1)$ & $(2)$ & $(3)$ & $(4)$ & $(5)$ \\
\hline & $\begin{array}{c}\text { Total Giving } \\
\text { Capital Purposes }\end{array}$ & $\begin{array}{c}\text { Total Giving } \\
\text { Current Operations }\end{array}$ & $\begin{array}{l}\text { Restricted to Athletics } \\
\text { Current Operations }\end{array}$ & Average Giving & Average to Athletics \\
\hline Title IX year - 2 & $\begin{array}{l}-0.049 \\
(0.100)\end{array}$ & $\begin{array}{c}0.135 \\
(0.170)\end{array}$ & $\begin{array}{c}0.272 \\
(0.258)\end{array}$ & $\begin{array}{c}0.131 \\
(0.173)\end{array}$ & $\begin{array}{c}0.279 \\
(0.254)\end{array}$ \\
\hline Title IX year - 1 & $\begin{array}{c}0.087 \\
(0.107)\end{array}$ & $\begin{array}{c}0.212 \\
(0.168)\end{array}$ & $\begin{array}{c}0.120 \\
(0.276)\end{array}$ & $\begin{array}{c}0.209 \\
(0.172)\end{array}$ & $\begin{array}{c}0.143 \\
(0.267)\end{array}$ \\
\hline Title IX year & $\begin{array}{l}-0.053 \\
(0.119)\end{array}$ & $\begin{array}{l}0.397 \\
(0.250)\end{array}$ & $\begin{array}{l}-0.016 \\
(0.240)\end{array}$ & $\begin{array}{l}0.370 \\
(0.255)\end{array}$ & $\begin{array}{c}-0.029 \\
(0.228)\end{array}$ \\
\hline Title IX year + 1 & $\begin{array}{c}0.013 \\
(0.136)\end{array}$ & $\begin{array}{c}0.467 \\
(0.290)\end{array}$ & $\begin{array}{l}-0.151 \\
(0.243)\end{array}$ & $\begin{array}{l}0.470 \\
(0.288)\end{array}$ & $\begin{array}{l}-0.126 \\
(0.221)\end{array}$ \\
\hline Title IX year +2 & $\begin{array}{c}0.179 \\
(0.206)\end{array}$ & $\begin{array}{c}0.467 \\
(0.341)\end{array}$ & $\begin{array}{c}0.123 \\
(0.290)\end{array}$ & $\begin{array}{c}0.444 \\
(0.343)\end{array}$ & $\begin{array}{c}0.129 \\
(0.269)\end{array}$ \\
\hline Observations & 7495 & 7429 & 5291 & 7429 & 5291 \\
\hline Clusters & 654 & 658 & 458 & 658 & 458 \\
\hline University FE & yes & yes & yes & yes & yes \\
\hline Year FE & yes & yes & yes & yes & yes \\
\hline University-specific linear trends & yes & yes & yes & yes & yes \\
\hline
\end{tabular}

Notes: Regression models evaluate the natural log of the outcome variables. See Table 6 for additional notes. $*, * *$, and $* * *$ indicate statistical significance at the ten, five, and one percent levels, respectively. 